\title{
FUNDAMENTOS DA RACIONALIDADE ESTÉTICA NA ANALÍTICA DO BELO KANTIANA
}

Jayme Paviani*

SÍNTESE - Interpretação de aspectos relevantes da Analitica do Belo da Critica da Faculdade do Juizo de Kant sob a perspectiva de uma fundamentação da racionalidade estética.

PALAVRAS-CHAVE - Racionalidade Estética. Juizo Estético. Juizo Reflexivo.
ABSTRACT - This article deals with relevant aspects of the Analytic of the Beautiful in Kant's Critique of Judgment from the standpoint of the foundations of aesthetic rationality.

KEY WORDS - Aesthetic Judgment. Aesthetic Rationality. Reflexive Judgment.

Uma introdução à leitura da analítica do belo kantiana exige o esclarecimento de alguns pressupostos. Antes de tudo, Kant ao publicar a Crítica da Faculdade do Juízo, em 1790, dois anos depois da Crítica da Razão Prática, em 1788, e nove anos depois da Crítica da Razão Pura, em 1781, apresenta, no dizer de comentaristas, o ponto culminante de seu sistema filosófico desenvolvido de modo gradual e contínuo. Nem todos, no entanto, vêem a terceira Crítica deste modo. Para Schopenhauer, por exemplo, a Crítica da Faculdade do Juizo tem dificuldades de tema, de estilo e é artificial enquanto sistematização. Os estudiosos, em geral, concordam quanto à complexidade da obra. Seu texto é visto como obscuro e polêmico. Para uns, ele indica uma certa decadência do pensamento kantiano e, para outros, ele é o coroamento do sistema kantiano.

A complexidade da Crítica da Faculdade do Juízo deriva, em grande parte, da tentativa de Kant reconciliar e superar o "abismo" entre os mundos da natureza e da liberdade, investigados separadamente nas Críticas anteriores. Essa constatação exige que se indague os motivos ou as razões que levaram Kant a escrever a terceira Crítica. Parece que ele não a havia previsto. Todavia, as questões do gosto, do conhecimento sensivel e do problema estético em geral pertencem ao século XVIII. Kant encontra-se no centro do debate e das posições empíricas e raciona-

* Professor do Departamento de Filosofia da PUCRS.

\begin{tabular}{|l|l|l|l|l|l|}
\hline VERITAS & Porto Alegre & v. 45 & n. 4 & Dezembro 2000 & p. 509-526 \\
\hline
\end{tabular}


listas. Com suas Críticas pretende superar essas teses antagônicas. A terceira Crítica oferece um novo estatuto para racionalidade, embora permaneça em estado problemático a solução transcendental que ele dá às questões do gosto, do belo, do sublime, do gênio e de outros conceitos vigentes na sua época.

Os empiristas afirmam a universalidade do juizo estético, porém, fora do sujeito, portanto, no objeto. Para eles, a razão não é uma faculdade dos fins. Os racionalistas tentam resolver a questão, mas, não de modo transcendental, pois, para eles, a razão apreende como fim algo exterior e superior, como o Ser, o Bem, concebidos pela vontade, o que, segundo Deleuze, torna a diferença entre empirismo e racionalismo menor do que se poderia acreditar (1976, p. 12).

Kant conhece as teorias estéticas anteriores. Sabe que Leibniz influenciou toda a filosofia do século e une as esferas do estético e da moral que, depois, ele separará. Conhece a demarcação que Wolff estabelece entre o conhecimento sensível e inteligível. Descartes havia afirmado que o belo é o verdadeiro revelado por idéias inatas e a arte é "imitação" idealizada da natureza. Para Locke todas as manifestações reduzem-se a sensações. Kant certamente conhece Sulzer, Mendeīssohn e Winckelman que escreveram sobre os sentidos e as sensações, os sentimentos agradáveis e desagradáveis, as belas-artes e a história da arte na antiguidade. Também é preciso lembrar, entre outros, Lessing, Herder, e o criador da estética como disciplina, o racionalista Alexandre Baumgarten (1714-1762), que define a estética como ciência do conhecimento sensível e o belo como perfeição do conhecimento sensível.

Alguns estudiosos da Crítica da Faculdade do Juízo surpreendem-se com o fato de Kant, filósofo pouco familiarizado com a arte, tenha produzido uma estética tão influente no Ocidente. Mas, o que se oferece nessa obra, especialmente na sua primeira parte, não é apenas uma analítica do belo e do sublime. Nela, ao se descobrir o juízo como faculdade, também se investigam os desejos humanos subjacentes e, conforme Hanna Arendt, sua leitura política nos permite algumas lições de filosofia política e de filosofia da cultura.

Kant, na Crítica da Razão Pura, ao referir-se à estética entendida como crítica do gosto, afirma que Baumgarten "tentou submeter a princípios racionais o julgamento crítico do belo", e realizou o esforço vão de elevar as regras ou critérios do gosto, que são apenas empiricos, a uma ciência. Para Kant tais regras não servem como leis determinadas a priori. Observa-se, assim, que as intenções kantianas já aparecem na primeira Crítica, embora se limitem apenas a comentar a esfera do gosto.

Uma leitura atenta da analítica do belo precisa levar em conta: a) as noções de estética, de gosto e de arte, antes da Crítica da Faculdade do Juízo; b) a antropologia subjacente ao sistema kantiano historicamente caracterizado e ligado às idéias de Jean-Jacques Rousseau e David Hume; c) o interesse transcendental que une e diferencia a ética e a estética kantiana. Esses e outros aspectos possibilitam, além de alcançar a "mens auctoris", reatualizar a questão estética kantiana. A investigação do belo, do sublime, do gosto etc., torna-se importante na medida 
em que nos apresenta as condições de uma racionalidade que se poderia chamar de "sensivel".

\section{A arquitetura do texto}

A terceira Crítica é menos simétrica do que as duas primeiras. Os temas, em geral, ultrapassam os limites da estrutura imposta. Pareyson afirma que em nenhuma outra crítica se percebe tanto a artificialidade na distinção, por exemplo, entre analítica, dedução e dialética (cf. L'Estetica di Kant, 1984). Segundo Adickes, só se compreende a filosofia kantiana, quando se pensa contra o andaime sistemático, pois Kant põe vinho novo em odres velhos (cf. Kants Systematik als system bildender Faktor, 1887).

A Crítica da Faculdade do Juízo exige uma leitura capaz de articular os aspectos intra-sistemáticos e a evolução dos conceitos. Há um desenvolvimento dos conceitos kantianos concomitante a uma permanência dos esquemas, e a necessidade de considerar que para Kant, também em relação à terceira Crítica, o método transcendental é o único modo legítimo de fundamentação da filosofia. A genealogia pré-crítica da Crítica da Faculdade do Juízo (as contribuições de empiristas e racionalistas), presente nas Observações sobre o Sentimento do Belo e do Sublime, de 1764, precisa ser vista na perspectiva global da filosofia kantiana. O leitor atento da analítica do belo não pode descuidar (a) o problema da redação da terceira Crítica; (b) o problema do método transcendental que define as relações entre os modos constitutivos sensível e inteligível do conhecimento e (c) o problema do juízo estético.

Tonelli mostra que a elaboração da Crítica da Faculdade do Juízo é fragmentada. Kant teria escrito, segundo os procedimentos recomendados em sua Antropologia (1779-1780) sobre a arte de escrever, a analítica do belo como projeto de uma crítica do gosto. Prova disso, além da correspondência de Kant, são as duas Introduções escritas para a terceira crítica. A antecedência isolada da analítica do belo decorre do fato de ele pressupor termos como "faculdade do juízo" (Urteilskraft), "juízo reflexionante" (reflektierendes) e "juízo determinante" (bestimmendes Urteil). Tudo indica que a primeira Introdução, bastante longa, foi escrita posteriormente à analítica do belo e antes da segunda parte, isto é, da critica da faculdade do juízo teleológica.

\section{O juízo estético como juízo reflexivo}

A Introdução definitiva (a), escrita depois do texto completo, substitui a primeira Introdução (b). Observa-se que a primeira (b) Introdução tem um caráter mais propedêutico, e a (a) segunda, enciclopédico. A primeira introduz a uma das partes do sistema a Crítica. A Segunda introduz o leitor no sistema global da crítica. A idéia de sistema aparece no início do século XVII como expressão comum de filósofos e teólogos. Kant não aceita a noção de sistema de Wolff e desenvolve este conceito na dialética transcendental da Crítica da Razão Pura. De certo modo, 
Kant reabilita o termo idéia da expressão "idéia de sistema" dos arquéticos de Platão, no sentido, para ele, de que a razão não se refere diretamente a um objeto, mas ao entendimento e, por meio deste, ao seu próprio uso empírico.

Uma das novidades da terceira Crítica, apresentada na Introdução, é a dos juízos reflexivos. Kant nas Críticas anteriores explica a função dos juízos, mas não lhe dá o status de faculdade, não estabelece o a priori da faculdade de julgar. Os juizos, em suas características gerais, requerem um esquema que permita fixar as regras para a subsunção do particular no conceito. A faculdade de julgar consiste, diz Kant, em "pensar o particular como contido no universal". Essa adequação entre o singular e o universal exige condições especiais. Nem todo ser humano é capaz de realizar bem esse ato. O próprio Kant adverte que existem pessoas eruditas incapazes de julgar. Trata-se de um talento que não pode ser ensinado. De fato, o juízo é um acordo entre as várias faculdades. Se o juizo for teórico, haverá no acordo predominância do entendimento. Se for prático haverá predomínio da razão, resultando um acordo entre a razão que legisla e o entendimento. Na terceira Crítica, fala-se de um acordo livre e indeterminado das faculdades. Nesse jogo livre nem a razão nem o entendimento legislam sobre o juízo. Kant distingue, de um lado, o juízo determinante, no qual a regra, o princípio, a lei é dada para poder afirmar o singular, e, de outro lado, o juízo reflexivo, no qual só o particular é dado, enquanto o universal deve ser encontrado.

No caso da justiça, o juízo determinante do juiz decide um fato particular subsumindo-o numa norma jurídica de validade universal. No caso do juízo estético, isto é, reflexivo, faltam conceitos gerais. Existem os fatos particulares, mas o juízo necessita do universal. Então esse universal é criado, projetado reflexivamente. Entende-se melhor a diferença entre o juízo determinante e o juizo reflexivo quando se distingue o juízo que julga do ponto de vista teórico e do ponto de vista ideal. O conceito universal do juizo reflexivo não é dado nem pelo entendimento nem pela razão, mas pelo juízo. Portanto, a faculdade de julgar prescreve uma lei, um universal, que não provém da "natureza", mas da reflexão sobre a "natureza".

Kant procura fundamentar o sentimento de prazer e desprazer. O que é objeto dos sentidos apresenta dois tipos de relações: a estética e a lógica. Na representação de um objeto, os elementos subjetivos constituem a natureza estética da representação e aquilo que determina o objeto em vistas ao conhecimento constitui sua validade lógica. O subjetivo da representação constitui-se no sentimento de prazer e desprazer. O fundamental, nesse sentido, está na conformidade a fins, isto é, a representação é estética porque se encontra ligada ao sentimento de prazer e de desprazer e não às características do objeto.

Tal processo é possível devido ao livre jogo, sem intenção, das faculdades da imaginação e do entendimento. O que é ajuizado é a forma do objeto na simples reflexão sobre ela mesma. Em outros termos, o que causa prazer não é a sensação ou o conceito vinculado ao objeto, mas sua forma. Kant esclarece que o fundamento para o sentimento do prazer e desprazer se encontra, na condição universal, ainda que subjetiva, nos juízos reflexivos. O fundamento está "na concordância conforme fins de um objeto (seja produto da natureza ou da arte) com a relação 
das faculdades do conhecimento entre si, as quais são exigidas para todo o conhecimento empírico (da faculdade da imaginação e do entendimento)" (CFJ, XIII). Assim, o juízo estético depende de uma pluralidade de faculdades que Kant jamais esclareceu totalmente. Esse objetivo de conciliar na faculdade do juízo as demais faculdades e representações permanece uma meta a ser alcançada.

A teoria kantiana dos juízos estéticos, teónicos e práticos é, na expressão de Loparic, "uma longa meditação sobre a finitude da razão humana". Os juízos teóricos baseiam-se só em conceitos objetivos, referem-se ao domínio de objetos empíricos. Podem ser determinantes ou reflexionantes. Os juízos práticos que empregam conceitos objetivos apenas no sentido prático, isto é, não especulativo, aplicam-se ao domínio das ações livres do homem. Dividem-se em técnicopráticos (imperativo hipotético) e moral-prático (imperativo incondicional). Os juízos estéticos empregam termos conceituais e termos valorativos, como agradável, belo, bom etc., sem valor objetivo. Dividem-se em juízos dos sentidos (sem pretensão à universalidade) e juizos reflexivos subjetivamente teleológicos e que têm pretensão à universalidade e à necessidade (cf. 1992, p. 55).

Um dos aspectos básicos da faculdade do juízo é o da imaginação que pode tornar presente no espírito o que está ausente na percepção sensível. Nesse sentido, a imaginação kantiana tem aproximações com o nous grego: olhar fixamente para coisas que estão presentes, embora ausentes de fato. Isso quer dizer: algo se apresenta ao espírito e não aos sentidos. Como explica Hanna Arendt (1993, p. 103 e 104), a faculdade da imaginação é a raiz comum das outras faculdades. Esta é uma das grandes descobertas de Kant. É a faculdade da síntese, do esquematismo envolvido em nosso entendimento. Quando desenhamos ou construímos uma casa particular e não a casa em geral, só o podemos fazer devido ao "esquema" ou eidos diante de nosso espírito.

O particular é verdadeiramente dado quando o processo reflexivo encontra o universal. Os juizos determinantes afirmam os casos particulares em relação a uma regra geral, segundo as leis do entendimento. O juízo reflexivo completa o juízo determinante, sem a ele se opor, legisla sobre si mesmo e não sobre o objeto, o qual lhe é indiferente.

\section{Uma racionalidade estética}

Outros aspectos podem ser mencionados para a leitura da Crítica da Faculdade do Juizo, no entanto, limitamo-nos a alguns pontos gerais. O termo "crítica" indica um exame aprofundado dos fundamentos, a capacidade de discernir o que a razão pode ou não pode fazer. Com o conceito de "faculdade", tema complexo, indica-se uma possibilidade básica. A expressão "faculdade do juízo em geral" aponta a possibilidade de pensar o particular contido no universal. Desse modo, além de uma apropriação dos significados dos termos usados e, especialmente, das diversas articulações entre "representações" e "faculdades", é necessário apontar para as contribuições, mesmo que problemáticas, das propostas kantianas sobre a natureza do estético como ponte entre o sensivel e o inteligivel. 
A investigação kantiana ultrapassa o projeto de uma Estética ou Teoria da Arte. Entretanto, essas ciências ou disciplinas pouco avançam sem o exame do problema do juízo estético posto como um juízo subjetivo (e não lógico), definido como lugar do sensivel e portador de uma modalidade específica de racionalidade. O estético pertence a uma esfera maior e anterior ao artístico e, além disso, lança pontes entre o mundo lógico (as formas puras de pensamento) e o mundo das emoções e dos sentimentos. A questão do juízo estético é difícil e obscura, tanto quanto é desafiadora e importante para esclarecer os limites da razão humana.

A revolução copernicana da filosofia de Kant, seu modo transcendental de conhecer, alcança na Crítica da Faculdade do Juízo um considerável alargamento e profundidade. A primazia do juizo substituindo de certo modo o problema do conhecimento determinado pelos objetos ou dos objetos. Só o juízo permite acesso ao belo e ao sublime, dois elementos centrais do estético. O estético está no juizo e não no objeto natural, técnico ou artístico. Tal constatação se torna possivel devido à função peculiar da faculdade de imaginar, pois, como diz Kant, "para distinguir se algo é belo ou não, referimos a representação, não pelo entendimento do objeto em vista do conhecimento, mas pela faculdade de imaginação (talvez ligada ao entendimento) ao sujeito e ao seu sentimento de prazer ou desprazer" (CFJ, I).

O sujeito não se reduz ao subjetivo, e o sentimento de prazer ou desprazer não é a simples sensação empírica. A pergunta o que é o belo é precedida pela indagação das condições de possibilidade do juízo estético. $\mathrm{E}$ as condições de possibilidade do juízo estético remetem a um conjunto de problemas filosóficos que hoje ganham nova importância com as pesquisas sobre a natureza e o funcionamento do cérebro-mente e sobre a corporeidade em geral. Nesse sentido, questionada a razão teórica, como fonte da produção humana, a Crítica da Faculdade do Juízo torna-se uma tentativa de encontrar uma racionalidade que não ignore o objeto nem elimine o sujeito ou, ainda, reduza tudo ao sujeito.

A investigação do belo resulta da busca de conexões entre as formas de conhecimento e os fins essenciais da razão humana. Contra o racionalismo e o empirismo, Kant procura estabelecer os verdadeiros interesses da razão. Em vista disso, a terceira Crítica não pode ser entendida isoladamente, pois as faculdades articulam-se entre si, segundo as fontes de representação (imaginação, entendimento, razão) e segundo as relações da representação em geral (conhecer, desejar, sentir).

A tentativa de caracterizar a forma superior do conhecer, do desejar e do sentimento de prazer e desprazer, permite concluir que Kant realiza um dos esforços mais radicais da história da filosofia para atingir a natureza do fenômeno estético e, desse modo, explicar o que se poderia chamar a razão sensível. Sem abandonar os fins da razão, Kant, com sua argumentação transcendental, reconhece uma racionalidade estética e, assim, caracteriza as condições racionais do estético ou, em outros termos, do pensar racionalmente o não lógico presente no juízo estético (na linguagem).

O lugar primeiro do belo (e do sublime) não é a obra de arte. O lugar adequado é o juízo estético porque implica a gênese e o desenvolvimento do estético, isto 
é, o critério de possibilidade que permite afirmar ou negar o estético enquanto elemento definidor do artístico ou, ao menos, de um certo grau de artístico, pois o estético é anterior ao artístico. Só depois de resolver o problema do conhecimento estético é possível explicar a produção da arte. Sem oferecer um estatuto adequado ao conhecimento "sensível" não se encontra o caminho de acesso à arte. As teorias que não observam isso se perdem na armadilha metafísica ou positivista, limitam-se a investigar a arte às vezes como natureza, outras vezes como liberdade, ainda outras vezes como algo meramente sensível ou, então, como algo suprasensivel. Nesse sentido, Kant contribui para resolver a questão das condições de possibilidade de conhecimento estético da obra de arte.

Se a arte tem como função básica a expressão estética, então é necessário determinar as características do conhecimento estético. Pois, a arte enquanto conhecimento não é acessível nem a uma investigação meramente "teórica" nem a uma abordagem exclusivamente empírica. Ela não é uma forma de conhecimento teórico ou empírico, mas uma "síntese" que engloba o sensível e o inteligível no juízo que nasce do sentimento de prazer e desprazer entendido no sentido kantiano.

A analítica do juízo do belo contém as possibilidades de entendimento, a produção e a recepção estética da obra de arte. A faculdade de julgar, de saber se algo se encontra subordinado ou não à determinada regra, conforme propõe na Crítica da Razão Pura, ou especificamente, no caso da Crítica da Faculdade do Juizo, de "pensar o particular como contido no universal" (XXV), permite o desenvolvimento da faculdade do sentimento de prazer e desprazer e, ao mesmo tempo, possibilita a existência de critério para demarcar o momento de "acabamento" no processo de produção e de recepção da obra. Nesta dimensão, a "obra de arte aberta" não é sinônimo de obra inacabada. A "abertura" da obra tem relação com o juízo estético. Ela é aberta enquanto a representação (a forma) da obra de arte é referida através da imaginação (talvez ligada ao entendimento) ao sentimento de prazer e desprazer do sujeito.

O juízo estético é a dimensão transcendental da percepção estética, entendida a percepção como distinta da sensação e definida como um fenômeno proposicional. A percepção estética alcança sua forma superior no juízo estético. A percepção não percebe objetos isolados, manchas, linhas, isto ou aquilo, mas fatos (no sentido do Tractatus de Wittgenstein) que se definem como pensamentos (cf. Frege). A percepção estética e o juízo estético não se referem à existência de objetos (coisas), mas à forma, à representação. Por isso, a análise do juízo estético antecede como condição o estudo da obra de arte. A obra de arte, ao distinguir-se das formas da natureza e do conhecimento teórico, é uma espécie de nova "natureza" e "conhecimento" específico. O resultado disso é o de um ente que se constitui como expressão de conhecimento que conserva e ao mesmo tempo transcende as relações sensível-inteligivel e imaginação-entendimento. A isso poder-se-ia chamar de uma nova forma de racionalidade que não é nem exclusivamente lógica nem sensível, isto é, uma racionalidade estética. 
A Crítica da Faculdade do Juízo procura resolver o problema da passagem entre o sensivel e o supra-sensivel (Deus), a conexão entre as legislaçöes do entendimento e da razão mediante a faculdade do juízo. A natureza segue a legislação do entendimento, como mostra o estudo da razão pura. A liberdade segue a razão pura prática, isto é, a legislação da faculdade de desejar. O "incomensurável abismo" entre os dois domínios é o problema filosófico kantiano.

Embora Kant tenha um modo próprio de entender a relação entre a natureza e a liberdade, entre o teórico e o prático, é necessário sublinhar a intenção kantiana de completar seu sistema através da crítica do juízo do gosto e da finalidade. Relevante é o esforço de determinação da passagem entre estes domínios, independente da validade das reflexões kantianas, de sua terminologia e do aspecto arquitetônico de seu sistema. O juízo de gosto e de finalidade esboça-se como uma forma específica de conhecimento que não é, no sentido rigoroso, nem um conhecimento empírico (razão prática), nem um conhecimento lógico ou objetivo (razão teórica).

Mostrar como o conhecimento estético situa-se num momento anterior ao dualismo sujeito e objeto, homem e mundo, exige um alargamento da racionalidade humana. Nessa perspectiva, as filosofias atuais, desde a analítica até a fenomenologia, têm raízes no solo da crítica do juízo, algumas privilegiando a linguagem (juizo) e outras a subjetividade. Em vista disso, certas filosofias, como a de Heidegger, que sublinham o modo de ser lingüístico do homem, são qualificadas como estetizantes. A partir da terceira Crítica, é possivel afirmar que o conhecimento estético constituído no juízo está na genealogia da distinção entre o conhecimento prático (do fazer e do agir) e o teórico e, por isso, pode ser entendimento como uma conexão entre os conhecimentos teóricos e práticos. A caracterização desse conhecimento estético estabelece igualmente uma nova relação entre a linguagem $e$ a realidade.

Na Crítica da Razão Pura, Kant afirma que os alemães são os únicos a usarem a palavra estética para designar o que os outros denominam crítica do gosto, denominação essa fundada na falsa esperança, concebida por Baumgarten, de submeter a avaliação crítica do belo a princípios racionais. Apesar dessa observação, podemos estender o significado de estético ao belo kantiano, cuja forma é o juizo estético.

A Crítica da Faculdade do Juizo apresenta duas formas de juizo de finalidade, o estético e o teleológico. O elemento novo do juízo estético é a reflexão. E o julgar é reflexionante quando somente é dado o particular e é preciso encontrar o universal. Tal operação não se realiza, nem exclusivamente pelo entendimento teórico (razão pura) nem exclusivamente pela razão prática. A faculdade de julgar basta-se a si mesma, sua fonte é a subjetividade, guia-se por idéias reguladoras, e não por idéias legisladoras, na tentativa de reunir os domínios da natureza e da liberdade.

O domínio do estético ultrapassa a apreensão dos dados da intuição das formas a priori do tempo e do espaço. Também vai além da finalidade cognitiva do entendimento. Ele abarca o âmbito do juizo cujo interesse é apenas o sentimento 
de prazer e de desprazer. A caracterização desse juízo (estético) como algo subjetivo e ao mesmo tempo ligado às condiçōes do sensus communis e da comunicação é um problema que Kant não consegue demonstrar de modo satisfatónio. Se a faculdade do juízo é puramente individual ou se necessariamente é social e individual na sua realização, é uma questão que requer a elucidação do sentido de "sensação", livre da finalidade cognitiva, e do sentido de "subjetivo", como lugar do "refletivo" que possibilita o particular com pretensão ao universal e ao necessário. Esses e outros aspectos constituem e esclarecem o caráter intersubjetivo e comunicativo do juízo estético.

O fenômeno estético presente na Crítica da Faculdade de Juizo, na parte relativa à analítica do belo, é examinado segundo o quadro das categorias da Crítica da Razão Pura, onde a função lógica do entendimento nos juízos, quanto à forma, obedece aos seguintes aspectos: (a) qualidade; (b) quantidade; (c) relação e (d) modalidade. O mesmo ocorre com a analítica do sublime, apesar de o paralelismo dessas análises ser superficial. A analítica do belo dá predomínio à qualidade. A analítica do sublime fornece destaque à quantidade. Tendo presente a natureza do juízo estético, é estranho que Kant use as categorias do entendimento. Isso demonstra que os juízos estéticos, como os juizos lógicos, dependem dos limites da razão, e são, sempre, instrumentos de determinação da experiência. Os juízos (teóricos, práticos e estéticos) enquanto juízos são esquemas formais. Sob o quadro categorial, portanto, podemos descobrir, identificar e analisar o estético segundo a ordem dos problemas que ele suscita.

$\mathrm{E}$ os problemas são imensos: como conciliar a subjetividade e a universalidade dos juízos estéticos? Como um juizo de gosto pode ser desinteressado? Como explicar a conformidade a fins e a necessidade do juizo estético? Como distinguir o agradável e o bom em relação ao belo? Kant emprega proposições que, sob o ponto de vista lógico, contêm oposições e contradições. Talvez seja preferivel afirmar que elas contêm paradoxos que desafiam a racionalidade lógica.

\section{O desinteresse como qualidade do juízo estético}

No início da analítica do belo, Kant afirma que, para distinguir se algo é belo ou não, a representação é referida (a) não pelo entendimento do objeto em vista do conhecimento, (b) mas pela imaginação, talvez vinculada ao entendimento, ao sujeito e ao sentimento de prazer e desprazer. Portanto, o juízo do gosto não é um juízo lógico de conhecimento, mas um juízo estético, isto é, seu fundamento é subjetivamente determinado. Para entender melhor é necessário ter presente que toda referência das representações é geralmente objetiva, mesmo a das sensações. Uma referência, no entanto, que não pode ser objetiva, é a referência ao sentimento de prazer e desprazer, pois nela não se designa absolutamente nada do objeto. Nessa referência o sujeito sente-se a si próprio do modo como é afetado pela sensação (CFJ, I).

Nesse sentido, a analítica do belo, sob o ponto de vista da qualidade, define o gosto como a faculdade de julgar um objeto ou um modo de representação medi- 
ante uma complacência ou descomplacência (agrado ou desagrado) independente de todo interesse. O objeto de uma tal complacência chama-se belo (CFJ, V). O belo independe de todo interesse sensível e racional, por isso, distingue-se do agradável e do bom. Para fazer tal distinção, Kant entende a sensação como uma representação objetiva dos sentidos e o sentimento como algo puramente subjetivo que não pode fornecer a representação de um objeto.

A sensação objetiva, própria do conhecimento sensível, indica o sujeito enquanto conhece. A sensação subjetiva, o sentimento, evoca o sujeito enquanto afirma que algo lhe agrada. O sentimento de complacência perante o belo deriva da reflexão sobre o jogo livre entre as representações intuitivas e conceituais de objetos. Por isso, o sentimento de prazer ou desprazer é uma espécie de autoconsciência, isto é, de posição do sujeito sobre si mesmo, de enunciado do sujeito sobre determinado estado subjetivo específico. O prazer estético não provém dos sentidos nem da razão. Só pode ser objeto de uma "satisfação" desinteressada. Portanto, o belo ou o prazer estético depende de como algo é julgado.

Nas primeiras Críticas, a satisfação ou complacência em geral é vista como um fenômeno empírico. Mas, a satisfação estética pura, independente de todo interesse, não leva em consideração a existência da coisa. Na Crítica da Razão Prática o termo "interesse", de suma importância, une-se ao de "liberdade como autonomia". De outro lado, a noção de "interesse" distingue-se da noção teórica de "intenção". Kant não nega a satisfação interessada, aquela que "representa" a existência de um objeto real. Apenas afirma que no juízo estético algo é belo na simples contemplação (intuição ou reflexão). A satisfação estética ou complacência é desinteressada, porque é adequado à beleza ser pura contemplação, isto é, não ser útil, não servir para fazer alguma coisa. Na relação sujeito e objeto, na faculdade do desejo, o sujeito torna-se juiz, parte interessada e o interesse prático é parcial. Na faculdade do gosto ou do juizo estético, o sujeito apenas mostra como é afetado pela representação e não pela existência do objeto. Há, portanto, uma clara distinção entre o "conhecimento representativo" que se refere ao objeto e a consciência reflexiva dessa representação unida à satisfação de prazer ou desprazer.

A satisfação ou complacência interessada e a desinteressada podem ser melhor explicitadas quando comparadas entre si. Kant, na Crítica da Faculdade do Juízo, não se ocupa com a sensação objetiva, isto é, a interessada, pois esse tipo de sensação, próprio do juízo de conhecimento, leva em consideração a existência do objeto. Tal sensação desperta o agradável, o que apraz aos sentidos. Kant investiga a sensação subjetiva, isto é, o sentimento não interessado do juízo estético do belo.

Ao afirmar que o juízo estético não é teórico, de conhecimento, mas sim subjetivo, significa, a partir dos princípios transcendentais, vir além da visão racionalista, mas sem abandonar o. caráter empírico do juizo que se origina na subjetividade. Estabelecendo a ponte entre o racional e o empírico, supera ao mesmo tempo o racionalismo, o empirismo e o subjetivismo. Assim como distingue o agradável do belo, também não confunde o bom com o belo. Bom é o que apraz median- 
te a razão pelo simples conceito. O agradável é dado aos sentidos através da existência do objeto ou mais precisamente através de algum atributo do objeto, por exemplo, a cor verde. O juízo que declara o objeto agradável implica o desejo de tal objeto. O agradável apraz, deleita, e o sujeito, além de aprová-lo, inclina-se a ele. O agradável não se julga (CFJ, III).

$\mathrm{O}$ bom apraz à razão pelo simples conceito. Ele é dado mediante o conceito do objeto que deve ser desse ou daquele modo. O bom para algo, isto é, o que apraz como meio ou o bom em si, que apraz por si mesmo, ambos contêm o conceito de um fim. Há uma razão na satisfação ou complacência fundada na existência de um objeto ou na existência de uma ação, tal razão implica um interesse qualquer. Para afirmar que algo é bom, preciso ter um conceito do objeto, mas não necessito de conceito para encontrar beleza no objeto. A beleza das flores, por exemplo, não depende de um conceito. A complacência no belo "depende da reflexão sobre um objeto, que conduz a um conceito qualquer (sem determinar qual), e desta maneira distingue-se também do agradável, que assenta inteiramente na sensação" (CFJ, IV).

\section{O caráter subjetivo e a validade universal do juízo estético}

Para Kant, o juizo moral distingue-se do juízo estético por referir-se aos fins da razão e, assim, permitir a possibilidade de universalização do imperativo categórico. O dever moral não é um conceito empírico, mas uma ordem a priori da razão, e a vontade é a faculdade de agir segundo certas regras. No entanto, o juízo estético não precisa da mediação do conhecimento para alcançar seu caráter universalizante, pois ele procede de modo reflexivo. Não necessita do conceito objetivo para ser universal. A complacência desinteressada do belo meramente apraz e, desse modo, deduz-se que é universal. A ética kantiana funda-se no predomínio da razão sobre os desejos. O juízo estético desloca o gosto dos sentidos (do agradável) para o gosto da reflexão (do belo), o qual não profere meramente juízos privados, mas pretensos juízos válidos (públicos) em relação a sua representação com o sentimento de prazer e desprazer (CFJ, VIII).

Essa universalidade não fundada em conceitos de objetos é estética e não lógica. Essa validade universal é subjetiva, pois não existem regras para dizer se algo é belo. Ocorre apenas que, quando se chama algo de belo (uma casa, um vestido, uma paisagem, um objeto) acredita-se ter a favor "uma voz universal" e reivindica-se "a adesão de qualquer um, já que do contrário cada sensação privada decidiria só e unicamente para o observador e sua complacência" (CFJ, VIII). Há, portanto, no juizo estético uma concordância entre a exigência de aprovação geral (pretensão de universalidade) e a quantidade lógica singular. Esta concordância é uma espécie de equilíbrio entre o racional e o irracional. A universalidade é apenas postulada sem a ajuda de conceitos. O juízo estético não exige a aprovação de cada um, mas que a aprovação seja considerada como uma "espécie" de regra. Nesse caso, Kant, graças ao entrelaçamento entre entendimento e imaginação, aceita a ausência de conceitos na comunicabilidade universal da representa- 
ção que não se refere ao objeto, mas que possibilita, através da reflexão, o juízo estético.

Como conciliar universalidade e subjetividade? Kant oferece como solução desse problema a distinção entre juízos acerca do agradável (portanto, privados, e denominados de "gosto dos sentidos") e juízos "públicos" (considerados em geral válidos e chamados de "gosto da reflexão"). Só no segundo caso, os juízos são desinteressados e configuram uma autopercepção reflexiva. Neles, pode-se afirmar, ocorre uma reivindicação de validade universal e não conceitual.

Sob o ponto de vista da quantidade, o juízo do gosto não exige por si mesmo a adesão de cada um, mas a atribui a cada um. Essa adesão está fundada numa comunicabilidade universal subjetiva das representações, isto é, na sociabilidade da natureza humana, explicitada como uma espécie de sensus communis (CFJ, XL). Essa "voz universal" não é imposta, mas apenas atribuída. Não existem regras empíricas para impor um juízo de gosto. Existe apenas uma disposição comum a todos. Os desacordos estéticos são apenas erros no modo de perceber o belo dentro de si ou a simples falta de atenção no essencial.

\section{A conformidade a fins sem a representação de um fim}

Sob o ponto de vista da relação, o belo, no juízo estético, supõe uma finalidade sem a idéia de fim. Essa finalidade não procurada da beleza "é a forma da finalidade" de um objeto, enquanto se dá sem a representação de um fim.

Kant atribui importância à forma e propõe uma distinção entre fim e forma finalis. O fim refere-se ao objeto com fundamento real de suas possibilidades e a forma finalis é a causalidade de um conceito relativamente a seu objeto. O fim é aquilo cujo conceito considera o fundamento de possibilidade do objeto mesmo, do objeto em si. Entretanto, para se poder representar um fim é necessário ter antes o conceito do objeto, isto é, a forma da finalidade. No caso da obra de arte, como em relação a qualquer objeto estético, pensa-se, mediante conceito, em um fim. Mas como o fim só pode ser pensado como conceito, a representação (fundamento determinante) que está em causa no juízo estético é a forma finalis ou causa determinante do fim. Em conseqüência, o fim do objeto ou o fim objetivo cautsa prazer interessado e corresponde no juízo ao bom e não ao belo. No juízo estético, entretanto, entram em relação as faculdades de representação - imaginação, entendimento e desejo - determinadas pela representação e não as qualidades objetivas do objeto.

A concordância entre a imaginação e o entendimento não é com o objeto, mas com a sua forma. Por isso, o sujeito não encontra nenhum fim determinado, nenhum interesse sensível ou racional. O que está em questão é a simples forma da finalidade na representação do objeto dado. 0 juízo estético puro não mistura 0 belo com atrativos e comoções nem com o conceito de perfeição. $O$ belo independe de conceitos, seja de utilidade ou de perfeição. Deve-se operar distinções, portanto, entre fim, finalidade e forma da finalidade. O fim caracteriza o fundamento que possibilita o objeto próprio do juízo do agradável, a finalidade consiste 
na possibilidade de representação conceitual do fim próprio do juízo do bom, e a forma da finalidade é a finalidade considerada apenas formalmente própria do juízo estético. Nesse sentido, o juízo estético é totalmente independente do conceito de perfeição, pois a perfeição como a utilidade são atinentes a um fim determinado pelo conceito, enquanto o belo corresponde a um fim formal.

Em relação à beleza, Kant distingue a beleza livre, pura, que não depende do conceito do objeto e a beleza aderente, condicionada, que pressupõe o conceito do objeto e até a noção de perfeição. Em síntese, a beleza não é uma idéia em si ou no objeto, nem um conceito ou propriedade objetiva de um objeto, mas um ideal a ser realizado pela imaginação, sem conceito. $O$ ideal de beleza que pode ser comunicado, porém, sem demonstração, nas palavras de Kant, "é a forma da conformidade a fins de um objeto, na medida em que ela é percebida nele sem representação de um fim" (CFJ, XVII).

\section{A necessidade do juízo estético}

O belo, deduzido do momento da modalidade, é sem conceito, reconhecido como objeto de um prazer necessário. Não se trata, porém, de uma necessidade objetiva teórica nem de uma necessidade prática. A necessidade do belo enquanto é pensada em um juízo estético é simplesmente exemplar, isto é, resulta do "assentimento de todos a um juízo que é considerado como exemplo de uma regra universal que não se pode indicar" (CFJ XVIII). Essa necessidade própria do juizo estético não pode deduzir-se de conceitos determinados, pois o juízo de gosto é subjetivo e também não pode provir da universalidade da experiência, pois a experiência não possibilita juizos universais. A necessidade do juízo estético baseia-se na idéia de um sentido comum, distinto do entendimento comum ou senso comum. É o sentimento comum, entendido como um princípio subjetivo, que determina a validade universal do juízo estético. Esse sentimento nasce do jogo livre e harmonioso das faculdades e possibilita alcançar o ideal de beleza. Assim, Kant conclui que "belo é o que é conhecido sem conceito como objeto de uma complacência necessária" (CFJ, XXII).

\section{O belo e o sublime}

A distinção entre os sentimentos do belo e do sublime, já esboçada em 1764, é investigada e sistematizada de modo transcendental na Crítica da Faculdade do Juízo. Diversos aspectos são apontados. O sublime, por exemplo, não se encontra na natureza, mas no espírito. Está nas idéias da razão e não nas formas sensíveis. O belo depende do entendimento e da imaginação, o sublime do domínio do supra-sensível que é o da razão e da imaginação.

$\mathrm{Na}$ analítica do belo destaca-se a categoria da qualidade, na analítica do sublime predomina a categoria da quantidade. Sublime é o que é grande absolutamente, e uma grandeza absoluta só pode ser da razão, pois exige o despertar de uma faculdade supra-sensivel. O sublime requer a ultrapassagem do mundo sensi- 
vel para o mundo do supra-sensível. Em vista disto, o belo propicia prazer e o sublime desprazer. No sublime o homem toma consciência de que pode ultrapassar toda a medida dos sentidos. A natureza não é sublime porque desperta o medo, mas porque permite que se considere a pequenez das coisas que inquietam a vida como a fortuna e a saúde. Assim, o sentimento do sublime assume em Kant uma força moralizadora e exige do homem uma cultura evoluída, uma educação da razão.

\section{A racionalidade do belo artístico}

Para Kant a arte é um produto da liberdade, obra de homens. Mas o belo artístico é pensado como natureza na arte, natureza que se suplanta na arte. Essa aparente contradição resolve-se com a distinção entre o produto criado e aquele que resulta meramente dos instintos. Por outro lado, entre os produtos criados, a arte diferencia-se dos produtos da ciência e dos ofícios. A arte, além de conhecimentos, requer a habilidade de produzi-la. Em relação aos ofícios penosos, desagradáveis e remunerados, a arte é livre e agradável.

A arte bela ou estética é aquela que visa ao sentimento de prazer. A arte agradável tem em vista o gozo, os atrativos que deleitam a sociedade, exige apenas uma sensação. Ao contrário, a arte bela, de caráter estético, requer reflexão e, assim, "promove a cultura das faculdades do ânimo para a comunicação em sociedade" (CFJ, XLIV).

Kant introduz o conceito de gênio para explicar a arte. Entende por gênio "a inata disposição do ânimo, ingenium, pela qual a natureza dá regra à arte" (CFJ, XLVI). O gênio, responsável pelas grandes obras artísticas, consiste no talento de produzir obras que não podem ser feitas a partir de regras determinadas. Há nele 0 "livre impulso da invenção". O gênio, além de talento, é aquele que cria modelos, exemplares que servem de padrão e regra de gosto e não imitações de outros. Para Kant é difícil descrever de modo científico a produção artística, pois nela existe uma espécie de natureza que fornece a regra. Em outras palavras, a natureza prescreve à arte a regra.

Apesar de Kant não ser um expert em arte, percebe-se na sua exposição a tentativa de conciliar na produção artística natureza e liberdade. A arte é ao mesmo tempo um "dom natural" e um produto da liberdade. Outra tentativa reside na conciliação entre gênio e gosto. Para a concepção kantiana, o gosto é a disciplina do gênio. Nessa afirmação é evidente a racionalidade estética que exige clareza e ordem na sensibilidade. Não a clareza e a ordem da lógica, mas aquela que articula imaginação, entendimento e gosto.

A idéia estética resulta da "representação da faculdade da imaginação que dá muito a pensar, sem que contudo qualquer pensamento determinado, isto é, conceito, possa ser-lhe adequado, e que conseqüentemente nenhuma linguagem alcança inteiramente nem pode tornar compreensível" (CFJ, XLIX). A norma artística de gosto, que assim provém da idéia estética, ultrapassa o estético ao ser também expressão do ético. $\mathrm{O}$ argumento está na natureza que apresenta fins em 
si, além da beleza, e indica desse modo que somos o último fim da criação. A arte bela, mesmo sendo arte, aparece tão livre de regras e de fins fixos que parece a natureza.

\section{Sociabilidade e fundamentação transcendental dos juízos estéticos}

Os juízos estéticos expressam a capacidade de julgar, de julgar o belo e o sublime. Esta capacidade de julgar tem sua base num sentir comum a todos os homens, no gosto como sensus communis (CFJ, XL). No caso do juízo estético do sublime aponta-se para uma dimensão moral do sentimento. Os juízos estéticos, apesar de suas características peculiares, têm origem e necessidade em princípios a priori, pois não dependem de condições externas, mas da relação entre as faculdades da sensibilidade, do entendimento e da razão e, apesar de suas condições subjetivas, realizam-se em todos os homens.

\section{Perspectivas de uma razão sensível}

A analítica do belo, de imediato, nada diz diretamente da obra de arte. Kant, de fato, além de afirmar que a arte é um produto da liberdade e que se fundamenta nos atos da razão e de que a arte é obra do gênio, isto é, da disposição inata do espírito, ingenium, pela qual a natureza dá suas regras à arte, acrescenta muito pouco à compreensão do processo de produção da arte. Sua contribuição decisiva está na ordem da racionalidade específica que possibilita tanto a produção da obra de arte quanto a sua recepção. O domínio do juízo estético é anterior e mais abrangente do que o domínio da obra de arte. Poder-se-ia dizer que o juízo estético constitui o núcleo da racionalidade estética e que o domínio da produção artística é o da racionalização estética.

Kant oferece elementos básicos para uma nova forma de racionalidade, a racionalidade sensível e estética que está presente no juízo estético. Realiza um supremo esforço de busca de uma "lógica" da sensibilidade, em primeiro lugar, mostrando que a sensibilidade, o entendimento e a razão existem de modo articulado e, em segundo lugar, demonstrando que o juízo estético opera com seus princípios próprios, portanto, livre das explicações racionalistas. A racionalidade estética é uma forma de conhecimento "vago" para os padrões do pensamento lógico. Entretanto, apesar das dificuldades epistemológicas inerentes ao seu processo de conhecer ligado ao sentir e ao imaginar, a racionalidade estética mostra a estrutura e a natureza do mundo da subjetividade e do sentimento que se expressa no domínio estético. Nessa perspectiva, o esforço kantiano de investigação da racionalidade do juízo estético, mesmo dependente do entendimento lógico, abre possibilidades novas de superação do dualismo entre o sensivel e o inteligivel.

As características do juízo estético implicam a existência de uma racionalidade que podemos chamar de estética. Por sua vez, a racionalidade estética torna-se o princípio que determina as condições da produção artística. Em outros termos, determina o que pode ser chamado de processo de racionalização ou de produção 
da obra de arte. No sentido mais amplo, no juízo estético articulam-se os aspectos subjetivos e objetivos, inaugura-se uma experiência subjetiva com exigências de uma concordância universal. Portanto, há uma racionalidade específica que passa necessariamente pelos sentidos, pela sensação (experiência estética), e alcança a intersubjetividade (percepção estética) e, mais ainda, a universalidade no juízo estético que nasce do livre jogo das faculdades humanas. Se, de um lado, o fundamento do juízo estético é o sentimento de prazer ou desprazer, de outro lado, sua condição de possibilidade reside no "dever sentir" atribuído pelo indivíduo a todos os homens.

$\mathrm{Na}$ racionalidade estética, ao contrário da lógica do conhecimento objetivo, o sensivel é admitido no inteligível como parte integrante e não como algo que deva ser excluído. Todavia, essa tentativa de superação dos limites entre o sensivel e 0 inteligivel, do subjetivo e do objetivo, permanece problemática, em Kant e em toda a filosofia ocidental, apesar dos avanços do pensamento contemporâneo. São quase inexistentes as investigações que procurem abrir caminhos de acesso ao conhecimento não objetivo. $\mathrm{E}$, paradoxalmente, embora o juízo estético kantiano proponha características de um novo "tipo" de racionalidade, a teoria estética enquanto teoria só pode ser elaborada dentro dos padrões da racionalidade objetiva.

Diante disso, uma das alternativas consiste em sair do domínio da teoria científica e filosófica e procurar no artístico a validade universal possivel das formas de contemplação (e não da sensação), onde os interesses particulares estão suspensos graças à liberdade de agir da imaginação em relação ao entendimento e à razão. Na realidade, a imaginação trabalha com a gênese do conceito e não com o conceito pronto, definido. O "sem conceito" kantiano presente no juízo estético é anterior aos processos de categorização que permitem entender qualquer objeto, é simplesmente o princípio da racionalidade estética que possibilita a racionalização da obra de arte enquanto produção e recepção, enquanto fabricação e apreciação estética.

\section{Referências bibliográficas}

\section{a) de Kant}

KANT, Immanuel. Crítica da faculdade do juizo. Trad. de Valério Rohden e Antonio Marques. Rio de Janeiro: Forense, 1993.

- Observações sobre o sentimento do belo e do sublime. Trad. de Vinicius de Figueiredo. Campinas: Papirus, 1993. 1995.

\section{b) sobre a Crítica da Faculdade do Juízo}

ADORNO, Theodor W. Teoria estética. Lisboa, São Paulo: Martins Fontes, s/d.

ARENDT, Hanna. Lições sobre a filosofia política de Kant. Rio de Janeiro: Relume Dumará, 1993.

CASSIRER, Ernst. Kant, vida y doctrina. México: Fondo de cultura económica, 1993.

DELEUZE, Gilles. Para ler Kant. Rio de Janeiro: Francisco Alves, 1976.

DUARTE, Rodrigo (org.). Belo, sublime e Kant. Belo Horizonte: Ed. UFMG, 1998.

GADAMER, Hans-Georg. Verdade e método. Petrópolis: Vozes, 1997. 
FERRY, Luc. Homo aestheticus. São Paulo: Ensaio, 1994.

JUNCO, Manuel Fontan. El significado de lo estétiço. Pamplona: EUNSA, 1994.

LEBRUN, Gérard. Kant e o fim da metafisica. Trad. de Carlos Alberto Ribeiro de Moura. São Paulo: Martins Fontes, 1993.

LYOTARD, Jean Francois. Lições sobre a analítica do sublime. Campinas: Papirus, 1991.

MARQUES, Antonio. Organismo e sistema em Kant. Lisboa: Presença, 1987.

PAREYSON, Luigi. L'Estetica di Kant. Lettura della Critica del Giudizio. Milano: Mursia, 1984.

SANTOS, Leonel R. As metáforas da razāo. Lisboa: Calouste Gulbenkian, 1993.

SCHOPENHAUER, Arthur. O mundo como vontade e representação. Lisboa: Res, s/d.

\section{C) Revistas, anais e artigos}

CORDUA, Carla. El juicio en la filosofia de Kant. Diálogo. Revista del Departamento de Filosofia de la Universidad de Puerto Rico, ano 22, n. 52, jul. 1988.

MARQUES, Tito. O desinteresse. $O$ que nos faz pensar. Cademos do Departamento de Filosofia da PUCRJ. Rio de Janeiro, n. 9, p. 60-72, out. 1995.

REVUE INTERNATIONALE DE PHILOSOPHIE. Kant "Critique de Jugement" (1790-1990), Paris, PUF, $1990,2 \mathrm{v}$.

ROHDEN, Valério (org.). 200 Anos da Crítica da faculdade do juízo de Kant, 1790-1990. Porto Alegre: Ed. da Universidade/UFRGS, Instituto Goethe/ ICBA, 1992.

TONELLI, Georgio. La formazione del texto della Kritik der Urteilskraft. Revue Internationale de Philosophie, fasc. 4, n. 30, p. 455-448, 1954. 